\title{
Michael Stausberg* \\ The Abyss of Intransitivity: On Critical Realism and Theories of Religion
}

https://doi.org/10.1515/zfr-2021-0024

From the mid-1970s onwards Hubert Seiwert published a series of pioneering works on the positioning of the study of religion/s (Religionswissenschaft) as an academic discipline. ${ }^{1}$ These were the days of the eclipse of the phenomenology of religion, when the need was felt to get more solid ground under one's feet in order to rejuvenate the discipline. Seiwert positioned himself in the camp of those who sought their refuge in the philosophy of science, in particular Critical Rationalism. Throughout his career as one of Germany's most prominent scholars of religion, Seiwert's work was informed by some recurrent leitmotivs: the importance of the philosophy of science, the duality and combination of the historical and systematic dimensions of the study of religion, and the status of Religionswissenschaft as an empirical science.

In a text from 2014, Seiwert claims that the empirical status of Religionswissenschaft opposes 'big theories"2 and he diagnoses an excess of theoretical selfreticence in the study of religion/s. Other disciplines, Seiwert thinks (and I concur), seem to be more at ease with theorizing about religion. ${ }^{3}$ Yet, it is doubtful whether it is the empirical character of our discipline that is the causal factor here: archaeology, anthropology and sociology, for example, are hardly less empirical, yet they are much more prone to theorizing. In addition, Seiwert finds that theory formation has a tendency to get detached from empirical materials and to develop

1 A list of Seiwert's publications (up to 2014) can be found in the Festschrift published in his honor (Franke, Kleine, and Mürmel 2014, 18-23).

2 Seiwert (2014, 22): „Die Zurückhaltung der Religionswissenschaft beim Formulieren allgemeinerer Theorien über Religion ist auch sachlich begründet, weil die Empirie sich gegen große Theorien sperrt.“

3 Seiwert (2014, 22f.): „Andere Disziplinen können unbefangener über Religion theorisieren. Vielleicht ist es aber auch so, dass in der deutschen Religionswissenschaft die Kritik an der Phänomenologie zu einem Übermaß theoretischer Zurückhaltung geführt hat, jedenfalls soweit es um den Gegenstand Religion geht.“

*Corresponding author: Michael Stausberg, University of Bergen,

E-Mail: Michael.Stausberg@uib.no

Ә Open Access. (C) 2021 Michael Stausberg, published by De Gruyter. (cc)BY under the Creative Commons Attribution 4.0 International License. 
(read: degrade) into self-referential discourses (Seiwert 2014, 22). From a philosophy of science point of view this is far from an aberration: "theories are tested not simply in relation to objects; they are tested in relation to other theories." (Jensen 2011, 44) Theories operate with abstract concepts without a direct anchoring in concrete data; they do not cover empirical data but offer overarching horizons of meaning (Burkard 2014, 50f.).

An "Empirical Discipline" (Seiwert 2020) is an academic enterprise that aims "to produce true knowledge about the world". This presupposes "that there exists a reality that is independent of the researchers that attempt to get knowledge about it." (Seiwert 2020, 213) Such a position is called realism. Adopting such a position is in line with Seiwert's earlier Popperian/Critical Rationalist position, but for one key argument of his recent article he draws on ideas from a rivaling school of the philosophy of science, namely, Critical Realism (CR). ${ }^{4}$ CR is probably more popular among social scientists than among professional philosophers (Baert 2005, 88). It seeks to avoid both reductionism and positivism (Bhaskar $1979,3)$. It seems to allow one to have the cake and eat it too.

The feature of CR that attracts Seiwert is the distinction, introduced by its main creator, the English philosopher Roy Bhaskar (1944-2014), between transitive and intransitive objects of knowledge. (Bhaskar was good at coining new terms, which some find enlightening, and others dismiss as obscure jargon.) Since this distinction is key to the second part of Seiwert's article, where he debates some of my views on theories of religion, I will take the occasion of this response to take a critical look at this building block of CR; this will once again take us back to the mid-1970s.

In A Realist Theory of Science (1975), a foundational text of CR, Bhaskar speaks of

this central paradox of science: that men [sic] in their social activity produce knowledge which is a social product much like any other, which is no more independent of its construction and the men [sic] who produce it than motor cars, armchairs or books, which has its own craftsmen, technicians, publicist, standards and skills and which is no less subject to change than any other commodity. This is the one side of "knowledge". The other is that knowledge is "of" things which are not produced by men [sic] at all: the specific gravity of mercury, the process of electrolysis, the mechanism of light propagation. None of these "objects of knowledge" depend on human activity. [...] Let us call these, in an unavoidable technical neologism, the intransitive objects of knowledge. The transitive objects of knowledge are [...] the raw materials of science-the artificial objects fashioned into items

4 In the study of religion/s, prominent recipients of critical realism include Jeppe Sinding Jensen and Kevin Schilbrack. 
of knowledge by the science of the day. They include the antecedently established facts and theories, paradigms and models, methods and techniques of inquiry available to a particular scientific school or worker. (Bhaskar 2008, 21; italics in the original)

In this passage, Bhaskar makes it clear that the realm of intransitivity is beyond that of human activity. The examples for intransitive objects of knowledge he provides are taken from nature. The matters commonly studied by scholars of religion/s-or the social sciences and historical research dear to us-fall categorically outside the purview of this distinction as the transitive dimension is defined as by principle unaffected by any sort of human activity, construction or intervention.

Yet, in The Possibility of Naturalism: a philosophical critique of the contemporary human sciences (1979) Bhaskar moved out of the orbit of the natural sciences. Here he theorizes the nature of social reality as, among other features, characterized by activity-dependence, conceptuality, historicity and as being pre-interpreted and relational. Undeterred by his previous naturalist stipulations and without any attempt at re-definition, Bhaskar continues to use the transitive-intransitive distinction. At one point he mentions "the intransitivity of both beliefs and meanings" (Bhaskar 1979, 28), which seems quite at odds with his earlier definition; I have trouble imagining beliefs and meanings that do not depend on human activity.

In another context, Bhaskar postulates that there are intransitive objects (or mechanisms) that exist "independently of their identification" $(1979,13)$; this is the "generic assertion that there is a state of the matter which is what it is, regardless of how we do view it, choose to view it or are somehow manipulated into viewing it.” (Archer 1998, 195) This is, as the CR social theorist Margaret Archer says, an assertion, or an axiomatic assumption, a transcendental or transcendent reality beyond the grasp of ordinary cognition or language, similar to the theological realm of the really real. Intransitive reality is beyond our knowledge, whereas all knowledge is transitive (and by implication open to correction). Nevertheless, for Bhaskar, scientific knowledge aims at intransitive reality, and "restoring the idea of an ontological realm distinct from science" makes it "possible for us to say that in a particular field, say social psychology, science is not being done" (Bhaskar 2008, 43). This is understandable, as science wants to avoid building castles in the air, yet access to intransitive ontology is only possible by means of transitive epistemology. Bhaskar, however, would dismiss this argument as "the epistemic fallacy", namely "that statements about being can always be transposed into statements about our knowledge of being" $(2008,16)$. An example of committing this fallacy, for Bhaskar $(2008,37)$, is "the prohibition on any transcendent entities". In other words, science needs to be open to transcen- 
dence. ${ }^{5}$ On this reading, CR rests on "the metaphysical claim to know a stratum of ultimate reality beyond knowledge” (Cruickshank 2004, 581); Cruickshank calls this project "hegemonic"; we could also call it gnostic, as a posture of knowledge of the ultimate. ${ }^{6}$

In another passage (partially referred to by Seiwert 2020, 220) Bhaskar distinguishes between the two principles of causal interdependency and existential intransitivity, which are both at work in the human/social sciences. Existential intransitivity is here explained as the independence of the objects of investigation from the processes of investigation (like the independence of religions from religious studies), while the principle of causal interdependency (not mentioned by Seiwert) refers to the causal interplay between knowledge-production and the production of the objects of knowledge. As he puts it, the human sciences are distinct from the natural sciences because "they are themselves an aspect of, and causal agent in, what they seek to explain.” (Bhaskar 1979, 60) Hence, contrary to the conclusion drawn by Seiwert, for Bhaskar, intransitive objects and theoretical perspectives are not an either or, but they go together; subjects and objects of the human sciences are not disentangled but connected (Bhaskar 1979, 204). Hence, as is the case with other objects and instruments of investigation, in principle CR would allow for religion to be an intransitive thing (explanandum) and a conceptual instrument in knowledge-production (explanans). Seiwert warns of "the phenomenological fallacy” of transforming concepts into phenomena (2020, 231). While this danger may be real, eliminating the intransitive status of religion as a 'thing' is not a necessary logical consequence of Bhaskar's incoherent and problematic distinction between the transitive and the intransitive. ${ }^{7}$

To illustrate the point further, let us take a look at how Bhaskar speaks about society:

Society, as an object of inquiry, is necessarily "theoretical" in the sense that, like a magnetic field, it is necessarily unperceivable. As such it cannot be empirically identified independent of its effects; so it can only been known, not shown, to exist [...] not only can society not be identified independently of its effects, it does not exist independently of them either. But

5 In German Religionswissenschaft, such a position has been advocated by Wolfgang Gantke.

6 Some main protagonists of CR have later in their careers experienced religious or spiritual conversions, most prominently Roy Bhaskar (Archer 2004; Bhaskar 2000). While Bhaskar sees his spiritual turn, which considers humans as "essentially God" (Bhaskar 2000) as a consequence of his earlier positions, some commentators (also within CR) found it subversive. In a book-length critique from a Marxist version of CR, Creaven (2010) emphasizes the underlying leftist/Marxist agenda of Bhaskar's spiritual project.

7 As acknowledged by Seiwert $(2020,218)$ this point was similarly made by Schilbrack (2017). 
however strange this is from an ontological point of view, it raises no special epistemological difficulties. (Bhaskar 1979, 57)

In other words: there is no data for society, but there is data for its effects; society does not exist independently from what it does. Society is imperceivable and theoretical, but that does not make it unreal. Seiwert, who cites this passage (2020, 220), concludes: CR "admits the existence of social realities that cannot be observed directly." This conclusion also suggests itself for religion, which operates likewise, arguably with at least one notable difference: humanity may be conceivable without religion, but not without society; just like language, society is a necessary condition for human action and intentionality, which may not be the case with religion. Another comparison is capitalism: (like society and religion) it is not identified independent of its effects; it is a lay concept and an academic concept with a European genealogy but transcultural applicability; it is a concept and a thing; it is historically contingent but has causal powers; and it is both explanans and explanandum.

While CR opens up a theoretical perspective that considers religion as a (intransitive) thing, it can also invoke a different perspective: phenomena themselves may be "false or in an important sense inadequate (for example superficial or systemically misleading)" while intransitivity refers to the conditions for these phenomena (Bhaskar 1979, 66). One reading is the Marxist one; Bhaskar's word choice makes one think of false consciousness. The Marxist CR theoretician Andrew Collier writes:

Further still, particular institutions and false beliefs about them may be in a functional relation, such that the false beliefs serve to preserve the institutions that they are about. Where institutions oppress a substantial number of people, they will only be stable if protected by such false beliefs. In such cases, to propound the truth is not just to criticize, but to undermine the institution. (Collier 1998, 446)

One can anticipate what such a 'critical' theory would be like. Maybe the idea of religion is the falsest of all, with criticizing and dissolving it serving as a means of emancipation and liberation. In fact, de-constructing religion has been high on the agenda of the so-called Critical Study of Religion.

Has CR more to offer for theorizing religion than the problematic intransitivity/transitivity-distinction picked up by Seiwert? I think so. For example, CR has become known for propagating the concept of emergence, which developed from Bhaskar's ideas on the stratified or layered nature of reality. In The Possibility of Naturalism Bhaskar $(1979,125)$ speaks of "synchronic emergence, on which the higher principles cannot be completely explained in terms of lower-order ones." Emergence is related to complexity, where a combination of elements on another 
level of structural organization yields properties or powers that are qualitatively different from the original elements without being mere aggregations: the "emergent wholes are more than the sum of their parts" (Pratten 2013, 256). This theoretical concept, it seems to me, could hypothetically be made fruitful for a theory of religion: for example, religion can re-arrange a heterogeneous ensemble of constituent elements, thereby creating different theoretical options. Such a line of thinking has recently been adopted by sociologist Christian Smith in his theory of religion, where he speaks of the emergent capacities, features and causal powers of religion (Smith 2017). This is no accident, as Smith cites CR as one of the key influences in his theory of religion. Smith holds religion to be "a real, distinctive, and enduring part of human life, and that we can describe its nature in specific terms" (Smith 2017, 21). The point here is not to propagate or defend Smith's theory, but to show that embracing CR does not close the door to a theory of religion. Indeed, CR can open onto a theory of religion in the sense that I have outlined elsewhere (Stausberg 2009; Stausberg and Engler 2016), but that is rejected by Seiwert.

While dismissing the desirability and possibility of a theory of religion, Seiwert advocates considering religion as the guiding 'theoretical perspective' of the study of religion/s. Adopting such a posture "may reveal structures and relationships that remain hidden from other perspectives, such as economics and politics." (Seiwert 2020, 227, 232) For adopting such a perspective to yield significant insights (like structures and relationships), it is better informed by a theory of religion; if it fails to do so, such a perspective risks being empty and blind.

\section{Bibliography}

Archer, Margaret. 1998. "Introduction: realism in the social sciences." In Critical Realism: Essential Readings, ed. by Margaret Archer, Roy Bhaskar, Andrew Collier, Tony Lawson and Alan Norrie, 189-205. London: Taylor and Francis.

Archer, Margaret Scotford, Andrew Collier and Douglas V. Porpora. 2004. Transcendence: Critical Realism and God. London: Routledge.

Baert, Patrick. 2005. Philosophy of the Social Sciences: towards Pragmatism. Cambridge/ Malden: Polity.

Bhaskar, Roy. [1975] 2008. A Realist Theory of Science. London/New York: Verso.

Bhaskar, Roy. 1979. The Possibility of Naturalism: a Philosophical Critique of the Contemporary Human Sciences. Brighton: Harvester Press.

Bhaskar, Roy. 2000. From East to West: Odyssey of a Soul. London/New York: Routledge.

Burkard, Franz-Peter. 2014. “Große Theorien und Trübe Mischungen.” In Religionswissenschaft zwischen Sozialwissenschaften, Geschichtswissenschaften und Kognitionsforschung, ed. by Edith Franke and Verena Maske, 49-54. Marburg: IVK - Religionswissenschaft. 
Collier, Andrew. 1998. “Explanation and Emancipation.” In Critical Realism: Essential Readings, ed. by Margaret Archer, Roy Bhaskar, Andrew Collier, Tony Lawson and Alan Norrie, 444-472. London: Taylor and Francis.

Cruickshank, Justin. 2004. "A Tale of Two Ontologies: an Immanent Critique of Critical Realism." The Sociological review (Keele) 52:567-585.

Franke, Edith, Christoph Kleine and Heinz Mürmel, eds. 2014. Devianz und Dynamik. Festschrift für Hubert Seiwert zum 65. Geburtstag, Göttingen: Vandenhoeck \& Ruprecht.

Jensen, Jeppe Sinding. 2011. “Epistemology.” In The Routledge Handbook of Research Methods in the Study of Religion, ed. by Michael Stausberg and Steven Engler, 40-53. London: Routledge.

Pratten, Stephen. 2013. "Critical Realism and the Process Account of Emergence." Journal for the Theory of Social Behaviour 43:251-279.

Schilbrack, Kevin. 2017. “A Realist Social Ontology of Religion.” Religion 47:161-178.

Seiwert, Hubert. 2014. "Religionswissenschaft zwischen Sozialwissenschaften, Geschichtswissenschaften und Kognitionswissenschaften." In Religionswissenschaft zwischen Sozialwissenschaften, Geschichtswissenschaften und Kognitionswissenschaften, ed. by Edith Franke and Verena Maske, 15-31. Marburg: IVK - Religionswissenschaft.

Seiwert, Hubert. 2020. "Theory of Religion and Historical Research: A Critical Realist Perspective on the Study of Religion as an Empirical Discipline.” Zeitschrift für Religionswissenschaft 28:207-236.

Stausberg, Michael. 2009. "There Is Life in the Old Dog Yet: An Introduction to Contemporary Theories of Religion.” In Contemporary Theories of Religion: A Critical Companion, ed. by Michael Stausberg, 1-21. London, New York: Routledge.

Stausberg, Michael and Steven Engler. 2016. "Theories of religion." In The Oxford Handbook of the Study of Religion, ed. by Michael Stausberg and Steven Engler, 52-72. Oxford: Oxford University Press. 